\title{
A new species of the genus Agastopbysis Miroshnikov, 2014 (Coleoptera: Cerambycidae) from China and corrigenda to the author's publications of 2013 and 2014
}

\author{
Новый вид рода Agastophysis Miroshnikov, 2014 \\ (Coleoptera: Cerambycidae) из Китая и исправления \\ к публикациям автора 2013 и 2014 годов
}

\author{
Alexandr I. Miroshnikov \\ А.И. Мирошников
}

Russian Entomological Society, Krasnodar, Russia. E-mail: miroshnikov-ai@yandex.ru
Sochi National Park, Moskovskaya str., 21, Sochi, Krasnodar region 354002 Russia.
Русское энтомологическое общество, Краснодар, Россия.
Сочинский национальный парк, ул. Московская, 21, Сочи, Краснодарский край, 354002, Россия.

KEY WORDS: Coleoptera, Cerambycidae, Apatophyseini, Agastophysis, new species, China, corrigenda.

КЛЮЧЕВЫЕ СЛОВА: Coleoptera, Cerambycidae, Apatophyseini, Agastophysis, новый вид, Китай, исправление опечаток.

ABSTRACT. Agastophysis meiyingae sp. n. from Tibet, China is described again as new to fully comply with the provisions of the International Code of Zoological Nomenclature (1999), because, due to an inadvertent omission of the Material section in the previous description of Agastophysis meiyingae Miroshnikov, 2014, the availability of that name has been jeopardized. Corrigenda are also provided for some of the recent publications of the author, including the one containing the description of $A$. meiyingae.

РЕЗЮМЕ. Из Тибета (Китай) снова как новый вид описан Agastophysis meiyingae sp.n., чтобы полностью удовлетворять требованиям Международного кодекса зоологической номенклатуры (1999), поскольку в связи с непреднамеренным пропуском раздела "Материал" в прежнем описании Agastophysis meiyingae Miroshnikov, 2014 пригодность этого названия подвергнута риску. Даны исправления опечаток в некоторых недавних публикациях автора, включая ту, которая содержит описание $A$. meiyingae.

\section{Introduction}

Recently I have already described Agastophysis meiyingae as a new species [Miroshnikov, 2014]. However, when preparing the layout of the volume for publication which contained the description, a text fragment concerning the studied material was inadvertently omitted. This was immediately corrected in a subsequent paper [Miroshnikov, Lin, 2014]. At the same time, despite that omission, the original description of A. meiyingae does contain holotype fixation in the form of colour pictures and the corresponding figure captions, i.e. "Holotype male". Information concerning provenance of the holotype is likewise available: "China, Xizang (Tibet) Prov.". In addition, the section "Etymology", albeit indirectly, but quite logically does indicate the holotype's repository, i.e. "Institute of Zoology, Chinese Academy of Sciences, Beijing, China". No wonder that not only the former two conditions for fully complying with the provisions of the International Code of Zoological Nomenclature [1999] (Code), but also the latter one, which is the most circumstantial, has already found recognition by most of colleague students (e.g. http://lully.snv.jussieu.fr/titan).

However, to be fully certain, I went on scrutinizing this problem and discussing it in due detail with many colleagues, including some commissioners of the International Commission on Zoological Nomenclature (ICZN). Their opinions concerning the availability of that species name were divided. Some specialists argued that, since all above provisions of the Code had been quite fully met at least formally in the original description of $A$. meiyingae Miroshnikov, 2014, this name be considered as available. However, a few other colleagues noted some uncertainty concerning the repository of the holotype which impeded, in their opinion, an undisputed recognition of the name as available because of a nonstrict observance of the corresponding $\S 16.4 .2$ of the Code. Among such supporters of the need to root out the problem through repeating publication of the same name as new are Dr. Thomas Pape (Natural History Museum of Denmark, Copenhagen, commissioner of ICZN) (a personal communication of July 8, 2014) and a few others. 
Considering the above situation, in order to exclude any possible misunderstanding or confusion as regards the name Agastophysis meiyingae Miroshnikov, 2014, and to ascertain its absolutely indisputable availability, Agastophysis meiyingae sp. n. is published here again. The more so as certain misleading statements have already appeared on the web, such as "Agastophysis meiyingae Miroshnikov, 2014: 27 ... - unavailable" because of "no material published" (Danilevsky, http:// www.zin.ru/Animalia/Coleoptera/rus/cer_edit.htm, version of 17 July 2014), which only add to the confusion.

For practical reasons it seems thereby advisable to completely repeat verbatim the descriptive part and illustrations contained in Miroshnikov [2014] so that the reader would have all information summarized in one place.

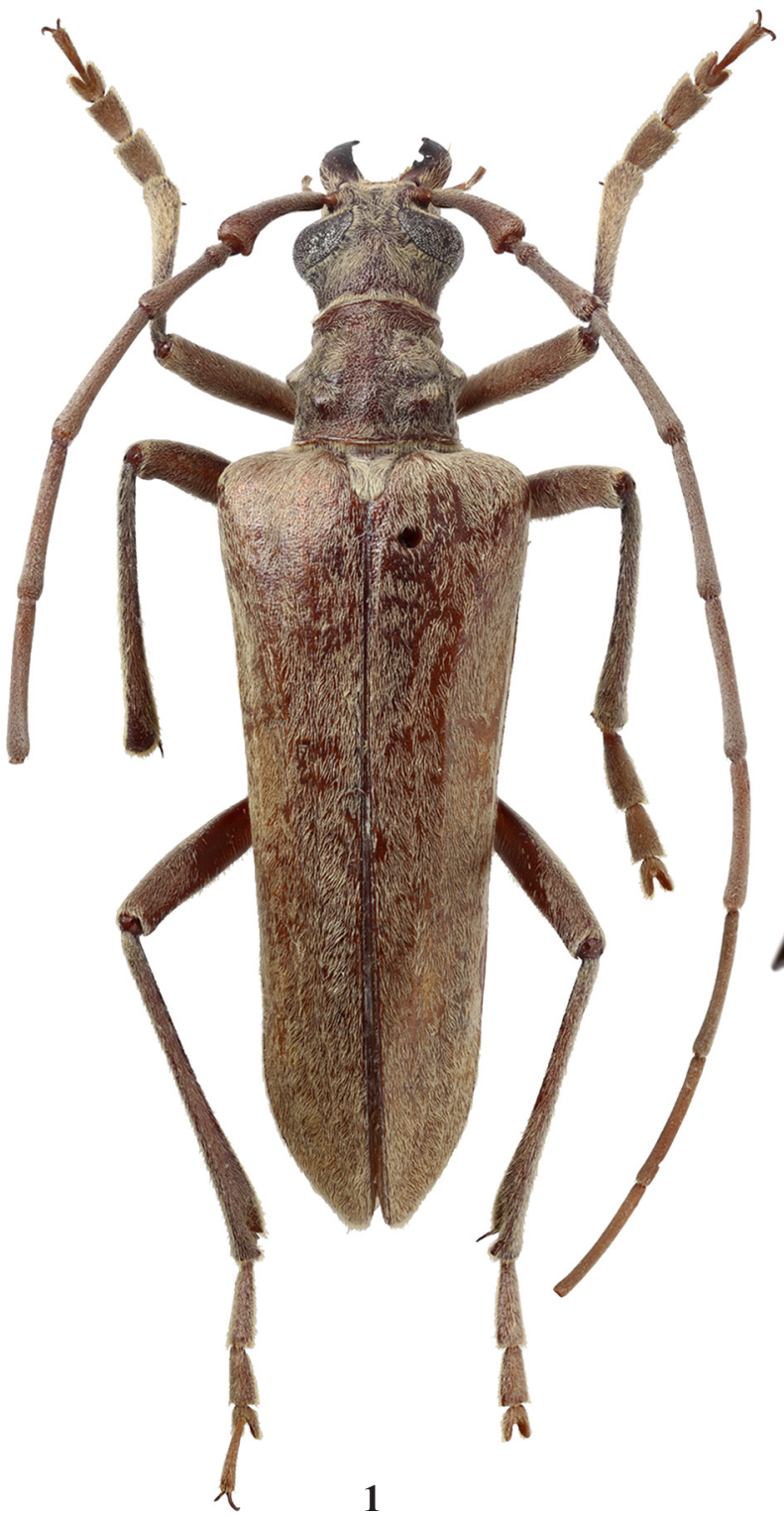

Agastophysis meiyingae Miroshnikov, sp.n.

Figs 1-3

Agastophysis meiyingae Miroshnikov, 2014: 27 (unavailable name?). Miroshnikov, Lin, 2014: 120 (unavailable name?).

MATERIAL. Holotype $\sigma^{T}$ [IOZ(E)1905118], China, Xizang (Tibet) Prov., Shannan Distr., Naidong, 1981, leg. Xin-Nian Li \& Bao-Hai Wang.

The holotype is kept in the Institute of Zoology, Chinese Academy of Sciences, Beijing, China (IZAS).

DIAGNOSIS. The new species is similar to Agastophysis griseopubens (Pic, 1957), but differs clearly by the elytra more elongated and more strongly narrowed towards the apex in the male, by certain features of the setation of the elytra which generally fails to form clear-cut longitudinal strips, by the more strongly developed pair of discal tubercles at the base of the pronotum in relation to the pair of tubercles before the middle, by an oblong scutellum, a somewhat different length ratio of antennomeres 1 and 4-6, and a larger body.

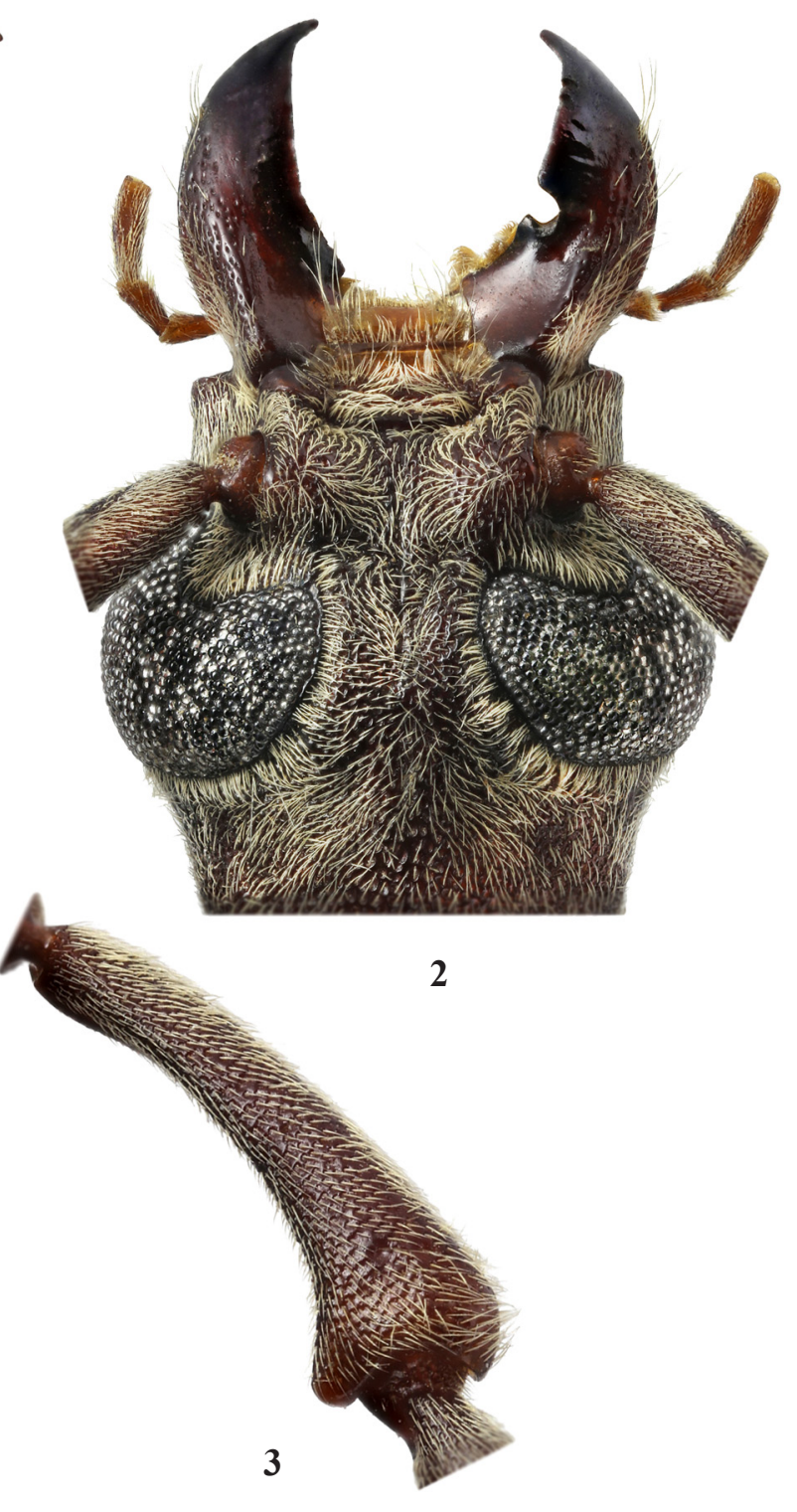

Figs 1-3. Agastophysis meiyingae sp. n., holotype male: 1 - habitus; 2 - head; 3 - right antennomere 1.

Рис. 1-3. Agastophysis meiyingae sp. n., голотип самец: 1 - общий вид; 2 - голова; 3 - 1-й правый членик усиков. 
DESCRIPTION. Male. Body length $22.5 \mathrm{~mm}$, humeral width $6.5 \mathrm{~mm}$. Reddish- and red-brown; eyes, as well as mandibles at inner margin and apically black.

Head with a dense, in places confluent, partly rugose, predominantly rough puncturation; antennae extending beyond apex of elytra by $9^{\text {th }}$ antennomere, reaching base of elytra by about basal one-third of $4^{\text {th }}$; antennomere $1,1.38$, $0.91,0.90$ or 0.89 times as long as $3^{\text {rd }}, 4^{\text {th }}, 5^{\text {th }}$ and $6^{\text {th }}$, respectively; antennomeres $7-10$ slightly differing in length.

Pronotum at level of lateral tubercles 1.10 or 1.23 times as wide as both width at base and length, respectively; base 1.26 times as wide as apex; apex with a sharp constriction; lateral tubercles at apex moderately acuminate; on disk, both upper and lower pairs of tubercles very clearly separated from each other by a strongly developed impression; lower pair of tubercles more strongly developed than upper pair; middle part of disk with a rough, dense, in places confluent puncturation (like on head), tubercles with a smaller dense puncturation.

Scutellum oblong, evidently narrowed towards apex, rounded at the very apex.

Elytra clearly narrowed towards apex; 2.6 times as long as width at base; with clear costae and an evidently less distinct puncturation than both head and disk of pronotum.

Pro- and mesosterna in apical part with clear transverse folds; metasternum with dense, small, rougher puncturation partly wrinkled in sutural area; sternites densely and finely punctured; apex of last (visible) sternite with a broad, very weak emargination.

Recumbent setation grey, well-developed, partly significantly or strongly hiding background sculpture; antennae, venter and legs with a more uniform setation than dorsum; longitudinal stripes of elytra generally almost not expressed, partly more or less visible only in apical half.

Female unknown.

ETYMOLOGY. The new species honours my colleague, Dr. Meiying Lin (IZAS), who kindly provided the material for study.

ACKNOWLEDGEMENTS. I am very grateful to all colleagues who actively participated in the discussion of the problem considered in the present paper.

\section{References}

International Code of Zoological Nomenclature. Fourth Edition. 1999. London: The International Trust for Zoological Nomenclature. xxix $+306 \mathrm{pp}$.

Miroshnikov A.I. 2014. New genera and species of the tribe Apatophyseini Lacordaire, 1869 from continental Asia, with notes on the little-known taxa (Coleoptera: Cerambycidae) // Konstantinov A.S., Slipiński S.A., Solodovnikov A.Yu. (eds.). Advances in studies on Asian cerambycids (Coleoptera: Cerambycidae). Papers by Alexandr I. Miroshnikov, dedicated to the memory of Dr. Judson Linsley Gressitt. Krasnodar-Moscow: KMK Scientific Press Ltd. P. 11-50

Miroshnikov A.I., Lin M.-Y. 2014. A new species of the genus Formosotoxotus Hayashi, 1960 from China, with additions to the description of Agastophysis meiyingae Miroshnikov, 2014 (Coleoptera: Cerambycidae) // Russian Entomol. J. Vol.23. No.2. P.117-120

\section{ERRATA}

As some of my previous publications contain some more misprints, their corrections are also offered below:

Konstantinov A.S., Ślipiński S.A., Solodovnikov A.Yu. (eds.). 2014. Advances in studies on Asian cerambycids (Coleoptera: Cerambycidae). Papers by Alexandr I. Miroshnikov, dedicated to the memory of Dr. Judson Linsley Gressitt. Krasnodar - Moscow: KMK Scientific Press Ltd. 237 pp.

$\begin{array}{lcc}\text { page } & \text { column } & \text { line } \\ 18 & \text { left } & 36 \\ 23 & \text { right } & 11 \\ 30 & \text { left } & 6-7 \\ 53 & \text { right } & 8 \\ 75 & \text { right } & 4-5 \\ 75 & \text { right } & 6 \\ 75 & \text { right } & 13 \\ 75 & \text { right } & 14 \\ 92 & \text { left } & 18 \\ 123 & - & 2 \\ 140 & \text { left } & 32 \\ 226 & - & 3\end{array}$

$$
\begin{gathered}
\text { As printed } \\
\text { bettles } \\
\text { metatibae } \\
\text { four species } \\
\text { the the type } \\
\text { antennomere } 4 \\
\text { antennomere } 3 \\
\text { antennomere } 4 \\
\text { antennomere } 3 \\
\text { fig } 1 \\
\text { from Sichuan } \\
\text { Figs 55-84 } \\
\text { photograph b }
\end{gathered}
$$

$$
\begin{gathered}
\text { Correct form } \\
\text { beetles } \\
\text { metatibiae } \\
\text { five species } \\
\text { the type } \\
\text { antennomere } 3 \\
\text { antennomere } 4 \\
\text { antennomere } 3 \\
\text { antennomere } 4 \\
\text { fig. } 1 \\
\text { from Yunnan } \\
\text { Figs 55-85 } \\
\text { photograph by }
\end{gathered}
$$

Miroshnikov A.I. 2013. The longicorn beetle genus Oligoenoplus Chevrolat, 1863 (Coleoptera: Cerambycidae) in China // Humanity space — International Almanac. Vol.2. No.1. P.238-246.
page
line
As printed
Correct form
243 